FOLIA POMERANAE UNIVERSITATIS TECHNOLOGIAE STETINENSIS

Folia Pomer. Univ. Technol. Stetin., Oeconomica 2018, 347(93)4, 103-112

Artur WILCZYŃSKI

\title{
WPŁYW SYSTEMU PRODUKCJI NA KOSZTY I DOCHÓD GOSPODARSTW PRODUKUJĄCYCH ŻYWIEC WOŁOWY
}

\author{
COSTS AND INCOME OF BEEF FARMS IN DIFFERENT \\ PRODUCTION SYSTEMS
}

Katedra Zarządzania Przedsiębiorstwami, Zachodniopomorski Uniwersytet Technologiczny w Szczecinie, ul. Klemensa Janickiego 31, 71-210 Szczecin, ORCID: 0000-0002-5019-1314 e-mail: artur.wilczynski@zut.edu.pl

\begin{abstract}
Summary. One of the major determinants of the economic results and the farm management is the production system. Exception in this area are not the farms which are located on the European Union. Factors affecting this situation are origin of calves used for fattening and the way of breeding beef cattle. The aim of this paper is to indicate the differences in production costs and income of farms in different beef production systems. The analysis used data from the agri benchmark Beef and Sheep network. The results shows that there is a dependence between beef production costs and the production systems. However, taking into farm profitability measured in net cash farm income, it cannot be indicate that the cow-calf farms are higher profitability than the farms based on cattle from dairy production.
\end{abstract}

Słowa kluczowe: dochód, gospodarstwa typowe, koszty produkcji żywca wołowego.

Key words: beef production costs, income, typical farms.

\section{WSTĘP}

Opłacalność produkcji rolniczej jest jednym z najważniejszych czynników wpływających na podejmowanie decyzji o zaniechaniu lub podjęciu produkcji określonych produktów rolnych. Bardzo ważne jest więc wskazanie, w jaki sposób kształtują się koszty produkcji oraz możliwe do uzyskania przychody ze sprzedaży produktów rolnych. Dlatego przedsiębiorca powinien być osobą aktywną, która poszukuje miejsca na rynku oraz sposobu działania, który pozwoli mu nie tylko przetrwać, ale i zapewnić dalsze istnienie, działanie i inwestowanie oraz zapobieganie zmianom, które mogą być dla niego niekorzystne (Wiatrak 2005).

Produkcja żywca wołowego uznawana jest w wielu regionach świata za gałąź o dużym znaczeniu dla rolnictwa i jego rozwoju. W Unii Europejskiej jej znaczenie nie jest tak duże, np. w krajach Ameryki Północnej i Południowej czy w Australii, ale charakteryzuje się wysoką dynamiką zmian, co potwierdza wzrost produkcji żywca wołowego i konsumpcji wołowiny wynoszący w latach 2013-2016 około 4\% (EU Agricultural outlook... 2017). Dlatego należy oczekiwać zwiększenia zainteresowania chowem bydła rzeźnego jako rozwiązaniem alternatywnym dla niestabilnego rynku mleka. Ważne jest podkreślenie, że producenci rolni mogą wybrać system produkcji żywca wołowego. Trudno jest zdefiniować 
taki system, jednak istnieją pewne parametry go opisujące. Należą do nich: położenie geograficzne, połączenie z innymi gałęziami produkcji rolnej (produkcja mleka, produkcja roślinna), źródło pochodzenia zwierząt przeznaczonych na opas (produkcja mleka, bydło ras mięsnych, procent zwierząt zakupionych czy z własnego chowu), system żywienia, kanały sprzedaży czy zarządzanie stadem (Deblitz i in. 2008).

Celem artykułu jest określenie różnic w kosztach produkcji i dochodu gospodarstw rolnych charakteryzujących się różnymi systemami produkcji żywca wołowego. Analiza została przeprowadzona na podstawie danych z gospodarstw typowych uczestniczących w badaniach realizowanych przez sieć agri benchmark Beef and Sheep.

\section{METODA I MATERIA}

Badania zostały przeprowadzone na podstawie danych ekonomiczno-organizacyjnych gospodarstw prowadzących chów bydła rzeźnego, które są wynikiem wieloletniej działalności sieci agri benchmark Beef and Sheep. Sieć powstała w 2001 roku w ramach międzynarodowej sieci gospodarstw porównawczych (International Farm Comparison Network). Celem jej było stworzenie podstaw analizy systemów produkcji rolniczej, zmian strukturalnych, technologicznych i związanych z polityką rolną na świecie oraz ułatwienie wymiany informacji pomiędzy ekonomistami zainteresowanymi analizą ekonomiczną na poziomie gospodarstwa (Hemme i in. 2014).

Sieć tworzona jest przez naukowców, doradców i producentów rolnych. Od początku jej istnienia aktywnym członkiem sieci są pracownicy Katedry Zarządzania Przedsiębiorstwami Zachodniopomorskiego Uniwersytetu Technologicznego w Szczecinie; prezentowane wyniki są odzwierciedleniem współpracy międzynarodowej z Thünen Institute of Farm Economics w Niemczech. Sieć agri benchmark Beef and Sheep działa na podstawie ściśle określonych zasad. Podstawowe znaczenie dla przeprowadzanych analiz mają gospodarstwa biorące udział w badaniach, które nazywane są gospodarstwami typowymi zdefiniowanymi, jako:

- gospodarstwa prowadzące opas bydła lub jako zestaw danych opisujących takie gospodarstwo,

- gospodarstwa położone w regionie o największym udziale gospodarstw prowadzących produkcję żywca wołowego w ogólnej liczbie gospodarstw zajmujących się jego produkcją w danym kraju;

- gospodarstwa o systemie produkcji (kombinacja czynników produkcji) reprezentującym większość gospodarstw na terenie danego państwa.

W badaniach sytuacji ekonomicznej gospodarstw rolnych metoda gospodarstwa typowego jest wykorzystywana przez wielu autorów takich, jak: Harwood (1979), Hatch i in. (1982), Dalgaard i in. (2006), Martins i in. (2014), Alig (2015), Trindade (2015).

Rozpoczęcie przez gospodarstwo typowe produkcji żywca wołowego następuje, gdy (Beef Report 2009):

- gospodarstwo zakupiło z zewnątrz cielęta lub odsadki (rasy mleczne i mięsne);

- dokonano transferu cieląt lub bydła w innym wieku z produkcji mleka lub chowu bydła mięsnego do opasania pochodzących $z$ tego samego gospodarstwa. 
Tabela 1. Sposób obliczania i charakterystyka poszczególnych parametrów ekonomicznych badanego gospodarstwa

\begin{tabular}{|c|c|}
\hline Nazwa kategorii & Sposób kalkulacji / charakterystyka parametru \\
\hline Koszty bezpośrednie & $\begin{array}{l}\text { zakup zwierząt, koszty zmienne, pasze zakupione, materiał siewny, środki } \\
\text { ochrony roślin, nawozy, koszty utrzymania maszyn, usługi obce }\end{array}$ \\
\hline Koszty gotówkowe & $\begin{array}{l}\text { koszty: zakupionych pasz, nawozów, materiału siewnego, paliwa, utrzymania } \\
\text { ziemi, dzierżawy ziemi, odsetki od kredytów, wynagrodzenia, opieki wete- } \\
\text { rynaryjnej i leków, wody, ubezpieczenia, prowadzenia ksiąg rachunkowych } \\
\text { itp. }\end{array}$ \\
\hline Koszty ogólnogospodarcze & $\begin{array}{l}\text { koszty, których nie można wyodrębnić i przypisać danemu kierunkowi } \\
\text { produkcji w gospodarstwie (np. koszty prowadzenia biura) }\end{array}$ \\
\hline Dochód rolniczy & $\begin{array}{l}\text { przychody ze sprzedaży + płatności bezpośrednie - koszty prowadzenia } \\
\text { działalności rolniczej (koszty bezpośrednie }+ \text { ogólnogospodarcze }+ \text { koszty } \\
\text { czynników produkcji) +/- zmiany w zapasach +/-zyski/ straty kapitałowe }\end{array}$ \\
\hline Przychody całkowite & przychody ze sprzedaży + płatności bezpośrednie \\
\hline $\begin{array}{l}\text { Koszty niezwiązane } \\
\text { z czynnikami produkcji }\end{array}$ & $\begin{array}{l}\text { koszty całkowite z wyłączeniem kosztów czynników produkcji (koszty pracy, } \\
\text { koszty ziemi, koszty kapitału). Koszty te zawierają: koszty zakupu zwierząt, } \\
\text { koszty zakupu i produkcji pasz własnych, utrzymanie maszyn, amortyzację } \\
\text { maszyn, koszty usług obcych, paliw, energii, utrzymania maszyn, utrzymania } \\
\text { i amortyzacji budynków, wody, opieki weterynaryjnej i leków, ubezpieczen,, } \\
\text { podatki i opłaty, koszty transportu i inne }\end{array}$ \\
\hline
\end{tabular}

Źródło: opracowanie własne na podstawie Beef Report 2008.

W sposobie kalkulacji kosztów produkcji żywca wołowego przyjętym przez sieć agri benchmark Beef and Sheep wyróżnia się dwie grupy: koszty niezwiązane z czynnikami produkcji i koszty związane z czynnikami produkcji (tab. 1). Koszty niezwiązane z czynnikami produkcji to wydatki poniesione przez organizację na zakup środków produkcji. Należą do nich m.in.: koszty pasz, koszty utrzymania maszyn, koszty nawożenia, podatki itd. Druga grupa kosztów zawiera koszty pracy najemnej, koszty kapitału obejmujące koszty odsetek od kredytów oraz koszty ziemi, w skład których wchodzą koszty czynszu dzierżawnego. Szczegółowe informacje na temat sposobu obliczania poszczególnych kategorii kosztów i kategorii dochodu uzyskiwanego z produkcji żywca wołowego zamieszczono w tab. 1. Należy zaznaczyć, że wyniki są przeliczane na wagę poubojową, a do bydła przeznaczonego na żywiec wołowy zalicza się: byki, wolce, jałówki, cielęta i krowy. Z kalkulacji wyłącza się bydło brakowane (produkcja mleka i chów bydła ras mięsnych).

\section{WYNIKI}

Badaniami objęto osiem gospodarstw typowych zajmujących się produkcją żywca wołowego z czterech krajów Unii Europejskiej. Zawarte w tab. 2 dane, dotyczące parametrów organizacyjnych chowu bydła rzeźnego pokazują, że podstawową determinantą stosowanego systemu produkcji jest źródło pochodzenia zwierząt do opasu (Oomen i in. 1998; Hocquette i in. 2011; Vries i in. 2015). Należy zaznaczyć, że według European Commission DG Agriculture and Rural Development można wydzielić trzy rodzaje gospodarstw prowadzących chów bydła rzeźnego, a mianowicie gospodarstwa:

- posiadające krowy mamki i nieprowadzące opasu bydła,

- prowadzące opas cieląt $z$ własnego chowu,

- prowadzące opas bydła pochodzącego z zakupu, czyli kończące opas. 
Tabela 2. Parametry organizacyjne badanych gospodarstw

\begin{tabular}{|c|c|c|c|c|c|c|c|c|}
\hline Parametr & DE-1 & DE-2 & ES-1 & ES-2 & PL-1 & PL-2 & FR-1 & FR-2 \\
\hline $\begin{array}{l}\text { Liczba zwierząt } \\
\text { poddawanych } \\
\text { ubojowi }\end{array}$ & 260 & 380 & 406 & 519 & 22 & 30 & 69 & 200 \\
\hline $\begin{array}{l}\text { Źródło } \\
\text { pochodzenia } \\
\text { zwierząt do opasu }\end{array}$ & $M$ & M & M / RM & $\mathrm{RM}$ & RM & M & RM & RM \\
\hline $\begin{array}{l}\text { Wiek zwierząt na } \\
\text { początku okresu } \\
\text { opasania [dni] }\end{array}$ & 53 & 35 & $30-200$ & 195 & 230 & 15 & 229 & 240 \\
\hline $\begin{array}{l}\text { Okres opasania } \\
\text { [dni] }\end{array}$ & 494 & 535 & $260-335$ & 180-232 & 210 & 535 & 235 & 300 \\
\hline $\begin{array}{l}\text { Waga początkowa } \\
\text { opasanych } \\
\text { zwierząt } \\
\text { [kg żywej wagi] }\end{array}$ & 87 & 83 & $50-175$ & $225-240$ & 290 & 60 & 305 & 312 \\
\hline $\begin{array}{l}\text { Waga końcowa } \\
\text { opasanych } \\
\text { zwierząt } \\
\text { [kg żywej wagi] }\end{array}$ & 721 & 699 & $440-552$ & $474-600$ & 490 & 530 & 600 & 735 \\
\hline
\end{tabular}

$\mathrm{M}$ - produkcja mleka, RM - chów bydła ras mięsnych.

Źródło: opracowano na podstawie bazy danych agri benchmark Beef and Sheep.

W typowych gospodarstwach niemieckich i polskich (typowych) systemem produkcji żywca wołowego oparty jest na opasie cieląt pochodzących z produkcji mleka. Natomiast w hiszpańskich czy francuskich mamy do czynienia z opasem bydła ras mięsnych. Wpływa to zarówno na wiek zwierząt, w którym rozpoczyna się okres tuczu, oraz na pozostałe parametry charakteryzujące system produkcji żywca wołowego. Opas cieląt ras mlecznych rozpoczyna się zazwyczaj w wieku od 2 do 8 tygodni, przy wadze mieszczącej się w granicach 60-100 kg. Inaczej wygląda ta sytuacja w przypadku, gdy mamy do czynienia z bydłem ras mięsnych, gdzie odsadki mają powyżej 0,5 roku i wagę 200-300 kg.

Pogłębiona analiza cech charakteryzujących system produkcji w badanych gospodarstwach wykazała, że gospodarstwa hiszpańskie prowadzą intensywny opas przemysłowy (feedlot). Opas ten jest składnikiem systemu produkcji, w którym dochodzi do największego zużycia energii na jednostkę wyprodukowanej wołowiny i najbardziej intensywnego użytkowania gruntów (Galyean i in. 2011). Jak wskazują Ferraz i in. (2010), feedlot stosowany jest przez około $18 \%$ życia bydła opasowego, w którym dawka pokarmowa zawiera wysokie stężenia błonnika i energii. W tym systemie prowadzona jest końcowa faza tuczu zwierząt trwająca zazwyczaj od 60 do 120 dni, w zależności od wagi zwierzęcia na początku okresu opasania oraz intensywności tuczu. Głównym celem stosowania tego system produkcji jest optymalizacja przyrostów, redukcja cyklu produkcji oraz podniesienie efektywności wykorzystania czynników produkcji (Carrer 2013).

Istotną informacją opisującą system produkcji jest żywienie bydła. W badanych gospodarstwach było ono oparte przede wszystkim na kiszonce z kukurydzy, ziarnie zbóż oraz koncentratach paszowych (ryc. 1). Sytuację taką potwierdzają m.in. badania: Nguyen i in. (2010), Ryschawy i in. (2012), Oomen i in. (1998). W gospodarstwach polskich oraz francuskim i niemieckim uzupełnieniem dawek żywieniowych była także kiszonka z trawy. 


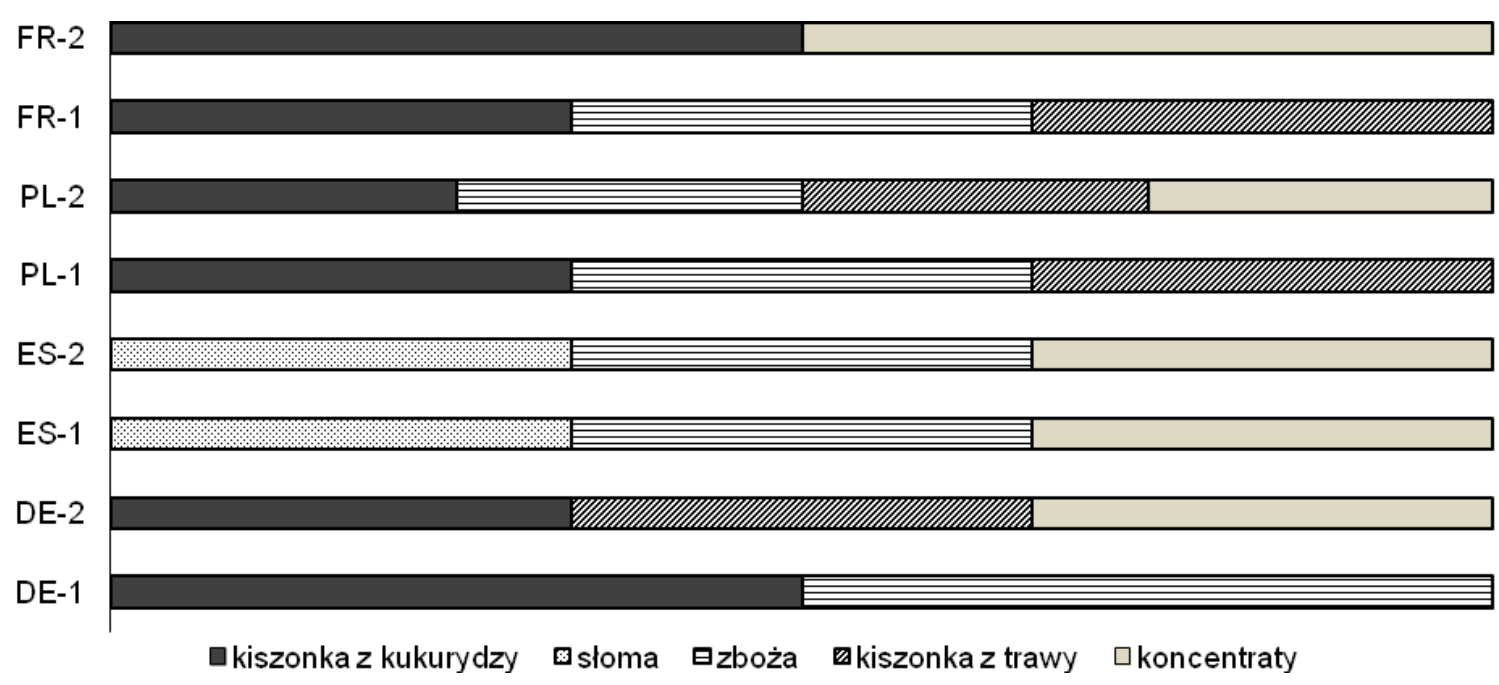

Ryc. 1. Graficzne odzwierciedlenie rodzaju pasz podawanych w badanych gospodarstwach Źródło: opracowano na podstawie bazy danych agri benchmark Beef and Sheep.

Zróżnicowana skala i struktura produkcji rolniczej wpłynęły na wielkość przychodów uzyskiwanych przez poszczególne gospodarstwa w 2016 roku (tab. 3). Przeprowadzone badania wykazują, że gospodarstwami, w których sprzedaż bydła stanowiła ponad $70 \%$ przychodów, były typowe gospodarstwa z Niemiec, Hiszpanii i jedno z gospodarstw francuskich. Natomiast w gospodarstwach polskich mamy do czynienia z produkcją wielokierunkową, gdzie źródłami przychodów są także produkcja mleka czy produkcja roślinna. Jak pokazują dane zamieszczone $w$ tab. 3 , dochód gospodarstw rolnych położonych na terenie Unii Europejskiej wspierany jest poprzez system płatności bezpośrednich, których udział w przychodach całkowitych mieścił się najczęściej w granicach od $5 \%$ do $30 \%$. Z wykonanej analizy wynika, że największym udziałem płatności bezpośrednich w przychodach całkowitych charakteryzowały się gospodarstwa polskie, co było związane między innymi ze skalą produkcji żywca wołowego.

Tabela 3. Wyniki ekonomiczne badanych gospodarstw w 2016 roku

\begin{tabular}{|l|r|r|r|r|r|r|c|c|}
\hline \multicolumn{1}{|c|}{ Parametr } & DE-1 & DE-2 & ES-1 & ES-2 & PL-1 & PL-2 & FR-1 & FR-2 \\
\hline Przychody całkowite & 1869 & 2212 & 1968 & 3210 & 189 & 595 & 800 & 1774 \\
\hline $\begin{array}{l}\text { Udział przychodów ze } \\
\text { sprzedaży bydła w } \\
\text { przychodach całkowitych [\%] }\end{array}$ & 90 & 100 & 100 & 84 & 48 & 20 & 56 & 77 \\
\hline $\begin{array}{l}\text { Udział płatności } \\
\text { bezpośrednich w przychodach } \\
\text { całkowitych [\%] }\end{array}$ & 7 & 8 & 11 & 16 & 55 & 27 & 25 & 10 \\
\hline $\begin{array}{l}\text { Koszty bezpośrednie } \\
\text { i ogólnogospodarcze [PLN] }\end{array}$ & 1313 & 1412 & 1814 & 2973 & 138 & 331 & 505 & 1325 \\
\hline $\begin{array}{l}\text { Koszty czynników produkcji } \\
\text { [PLN] }\end{array}$ & 91 & 308 & 8 & 83 & 16 & 71 & 28 & 103 \\
\hline $\begin{array}{l}\text { Udział kosztów bezpośrednich } \\
\text { w kosztach ogółem (z } \\
\text { wyłączeniem kosztów zakupu } \\
\text { zwierząt) [\%] }\end{array}$ & 71 & 54 & 89 & 88 & 54 & 66 & 61 & 71 \\
\hline Dochód rolniczy [PLN] & 465 & 492 & 146 & 154 & 35 & 193 & 267 & 346 \\
\hline
\end{tabular}

Źródło: opracowano na podstawie bazy danych agri benchmark Beef and Sheep. 
Dane zawarte w tab. 3 wskazują, że największy wpływ na wysokość kosztów całkowitych mają koszty bezpośrednie, których udział w kosztach całkowitych dochodził nawet do 90\%. Pozostałymi rodzajami kosztów mającymi znaczący wpływ na wielkość dochodu gospodarstwa były koszty ogólnogospodarcze oraz koszty czynników produkcji (z wyjątkiem gospodarstw hiszpańskich).

Przeprowadzone badania wykazały, że we wszystkich analizowanych gospodarstwach dochód rolniczy przyjmował wartości dodatnie, jednak jego wielkość była bardzo zróżnicowana. Najwyższe dochody osiągnęły gospodarstwa niemieckie, w których przekraczały one 450 tys. PLN. Natomiast jednym z najniższych dochodów charakteryzowały się gospodarstwa polskie. Potwierdza to także raport pt. „The EU cattle sector: challenges and opportunities-milk and meat wykonany przez Ihle i in." (2017) przygotowany na zamówienie European Parliament's Committee on Agriculture and Rural Development.

Wielkość przychodów ze sprzedaży żywca wołowego wskazuje na zróżnicowanie ceny skupu żywca wołowego w grupach państw „starej” i „nowej Unii” (tab. 4). Potwierdza to wielkość przychodów ze sprzedaży żywca wołowego uzyskiwanych przez gospodarstwa polskie, gdyż były one o ok. 300 - 400 PLN niższe za każde 100 kg sprzedanego żywca w wadze poubojowej. Pomiędzy pozostałymi gospodarstwami różnice te nie były zbyt duże i nie przekraczały 80 PLN na $100 \mathrm{~kg}$.

Tabela 4. Przychody ze sprzedaży i koszty produkcji żywca wołowego w badanych gospodarstwach

\begin{tabular}{|l|c|c|c|c|c|c|c|c|}
\hline $\begin{array}{c}\text { Przychody/koszty } \\
\text { [PLN/100 kg wagi poubojowej] }\end{array}$ & DE-1 & DE-2 & ES-1 & ES-2 & PL-1 & PL-2 & FR-1 & FR-2 \\
\hline $\begin{array}{l}\text { Przychody ze sprzedaży } \\
\text { żywca wołowego }\end{array}$ & 1431 & 1431 & 1510 & 1510 & 986 & 1116 & 1483 & 1447 \\
\hline $\begin{array}{l}\text { Koszty niezwiązane } \\
\text { z czynnikami produkcji }\end{array}$ & 871 & 927 & 954 & 785 & 1033 & 887 & 726 & 631 \\
\hline Amortyzacja & 177 & 201 & 51 & 63 & 343 & 51 & 233 & 154 \\
\hline Koszty gotówkowe & 761 & 938 & 907 & 726 & 816 & 1005 & 536 & 532 \\
\hline
\end{tabular}

Źródło: opracowano na podstawie bazy danych agri benchmark Beef and Sheep.

Analizując koszty produkcji, z wyłączeniem kosztów zakupu zwierząt, można wskazać na niższe koszty gotówkowe w gospodarstwach zajmujących się chowem bydła rzeźnego ras mięsnych, w porównaniu z gospodarstwami prowadzącymi opas bydła ras mlecznych. Widać to na przykładzie gospodarstw francuskich i niemieckich. Przeprowadzone obliczenia wykazały, że w 2016 roku w gospodarstwach francuskich koszty gotówkowe były o ok. 30-40\% niższe od kosztów ponoszonych przez typowe gospodarstwa niemieckie. Można to zaobserwować także w gospodarstwach polskich. W gospodarstwie dokonującym opasu cieląt ras mięsnych koszty gotówkowe są o prawie $20 \%$ niższe od ponoszonych w gospodarstwie korzystającym z materiału pochodzącego z produkcji mleka. Podobnie będzie w sytuacji, gdy analizie zostaną poddane gospodarstwa hiszpańskie.

Zawarte w tab. 5 dane, obrazujące strukturę kosztów produkcji żywca wołowego, wskazują na korelację pomiędzy systemem produkcji a kosztami pasz w gospodarstwach, w których podstawą żywienia jest kiszonka z kukurydzy (większość badanych gospodarstw), występują istotne różnice w zależności od źródła pochodzenia zwierząt przeznaczonych na opas. Fakt 
ten można zaobserwować, porównując ze sobą gospodarstwa polskie czy niemieckie z francuskimi. Uzyskane wyniki badań wskazują także na to, że w większości gospodarstw udział kosztów pasz w kosztach niezwiązanych z czynnikami produkcji mieścił się w przedziale od $30 \%$ do $50 \%$. Inaczej było w gospodarstwach hiszpańskich, co wynika ze specyficznego systemu żywienia bydła. Otrzymane wyniki pokazują także, że w gospodarstwach francuskich duży wpływ ma poziom kosztów produkcji miały koszty utrzymania maszyn i urządzeń, wraz z ich amortyzacją.

Tabela 5. Struktura kosztów niezwiązanych z czynnikami produkcji z wyłączeniem kosztów zakupu zwierząt

\begin{tabular}{|l|c|c|c|c|c|c|c|c|}
\hline \multicolumn{1}{|c|}{ Koszty [\%] } & DE-1 & DE-2 & ES-1 & ES-2 & PL-1 & PL-2 & FR-1 & FR-2 \\
\hline Koszty pasz & 48 & 38 & 74 & 64 & 34 & 43 & 24 & 33 \\
\hline $\begin{array}{l}\text { Koszty utrzymania } \\
\text { i amortyzacji maszyn } \\
\text { i urządzeń oraz usług } \\
\text { obcych }\end{array}$ & 20 & 18 & 5 & 4 & 29 & 5 & 36 & 34 \\
\hline $\begin{array}{l}\text { Koszty nośników } \\
\text { energii i wody }\end{array}$ & 9 & 14 & 4 & 4 & 19 & 29 & 9 & 9 \\
\hline $\begin{array}{l}\text { Koszty utrzymania } \\
\text { i amortyzacji } \\
\text { budynków }\end{array}$ & 11 & 18 & 3 & 7 & 12 & 4 & 11 & 8 \\
\hline $\begin{array}{l}\text { Koszty opieki } \\
\text { weterynaryjnej }\end{array}$ & 2 & 4 & 3 & 7 & 1 & 5 & 5 & 3 \\
\hline Podatki i opłaty & 4 & 3 & 3 & 2 & 3 & 3 & 5 & 4 \\
\hline Pozostałe koszty & 6 & 5 & 8 & 12 & 2 & 11 & 10 & 9 \\
\hline
\end{tabular}

Źródło: opracowano na podstawie bazy danych agri benchmark Beef and Sheep.

\section{PODSUMOWANIE}

Badania prowadzone w ramach sieci agri benchmark Beef and Sheep, oparte na analizie systemu produkcji w gospodarstwach typowych, wykazały, że najważniejszą jego determinantą jest pochodzenie bydła przeznaczonego na opas. Cielęta lub odsadki mogą pochodzić z dwóch różnych źródeł. Pierwszym z nich jest produkcja mleka, a drugim - opas bydła ras mięsnych. Wskazane źródła wpływają między innymi na organizację produkcji, koszty produkcji oraz wysokość dochodu gospodarstwa.

Analizując typowe gospodarstwa europejskie, można stwierdzić, że mamy do czynienia zarówno z gospodarstwami specjalizującymi się w chowie bydła rzeźnego, jak i gospodarstwami wielokierunkowymi, w których poza produkcją żywca wołowego prowadzona jest produkcja mleka czy produkcja mleka. Wykonane badania wykazały, że w gospodarstwach, w których udział przychodów ze sprzedaży żywca wołowego świadczy o ich wysokiej specjalizacji, mamy do czynienia z niższym poziomem kosztów produkcji. W szczególności można to zauważyć, gdy jest w nich prowadzony opas bydła ras mięsnych. Konsekwencją tego stanu rzeczy powinno być zachęcanie producentów rolnych decydujących się na chów bydła rzeźnego, aby przyjmowali właśnie taką strategię działalności.

Otrzymane wyniki badań pozwalają także na stwierdzenie, że kosztami, które w największym stopniu wpływają na wielkość kosztów produkcji żywca wołowego były koszty żywienia oraz koszty utrzymania maszyn (wraz z usługami obcymi). W większości 
analizowanych gospodarstw stanowiły one ponad $60 \%$ kosztów produkcji niezwiązanych z czynnikami produkcji. Dlatego to właśnie one powinny być w szczególny sposób badane przez producentów rolnych, gdyż mogą okazać się decydującymi o opłacalności produkcji żywca wołowego oraz mogą być źródłem powodzenia prowadzonej działalności rolniczej.

\section{PIŚMIENNICTWO}

Alig M., Sutter M., Nemecek T. 2015. Eco-efficiency of grass-based dairy systems in Switzerland. Grassland Sci. Eur. 20, 380-385.

Beef Report. 2008. Agri benchmark Beef Network. Brauschweig, Germany, Thünen Institute, 3-40.

Beef Report. 2009. Agri benchmark Beef Network. Brauschweig, Germany, Thünen Institute, 14.

Carrer M., Souza H., Vinholis M., Determinants of feedlot adoption by beef cattle farmers in the state of Sao Paulo. R. Bras. Zoot. 42(11), 824-830.

Dalgaard R., Halberg N., Kristensen I., Inger L. 2006. Modelling representative and coherent Danish farm types based on farm accountancy data for use in environmental assessments. Agriculture, Ecosystems and Environment 117, 223-237.

De Vries M., Middelaar C., De Boer J. 2015. Comparing environmental impacts of beef production systems: A review of life cycle assessments. Liv. Sci. 178, 279-288.

Deblitz C., Brömmer J., Brüggemann D. 2008. Beef production in Germany - production systems and their spatial distribution. Landbauforschung - vTI Agric. Forestry Res. 1/2(58), 29-44.

EU Agricultural outlook for the agricultural markets and income 2017-2030. 2017. European Union, 86, https://ec.europa.eu/agriculture/markets-and-prices/medium-term-outlook_sl, dostęp: 18.10.2018.

Ferraz J., Felicio O. 2010. Production systems - An example from Brazil. Meat Sci. 84, 238-243.

Galyean M., Ponce C., Schutz J. 2011. The future of beef production in North America. Anim. Front. 1, 29-36.

Harwood R. 1979. Small farm development. Understanding and improving farming systems in the humid tropics. Boulder, Colorado, Westview Press, Inc., 9.

Hatch T., Gustafson C., Baum K., Harrington D. 1982. A typical farm series: Development and Application to a Mississippi Delta Farm. J. Agric. App. Econ. 14(2), 31-36.

Hemme T., Uddin M., Ndambi O. 2014. Benchmarking cost of milk production in 46 countries. J. Rev. Global Econ. 3, 254-270.

Hocquette J.F., Chatellier V. 2011. Prospects for the European beef sector over the next 30 years. Anim. Front. 1(2), 20-28.

Ihle R., Dries L., Jongeneel, R., Venus T., Wesseler J. 2017. Research for AGRI Committee - The EU Cattle Sector: Challenges and Opportunities. Milk and Meat. Brussels, European Parliament.

Martins A., Goldsmith P., Moura A. 2014. Managerial factors affecting post-harvest loss: the case of Mato Grosso Brazil. Inter. J. Agric. Manag. 3(4), 200-209.

Nguyen T., Hermansen J., Mogensen L. 2010. Environmental consequences of different beef production systems in the EU. J. Clean. Prod. 18, 756-766.

Oomen G., Lantinga E., Goewie E., Van der Hock K. 1998. Mixed farming systems as a way towards a more efficient use of nitrogen in European Union agriculture. Environ. Poll. 102, 697-704.

Ryschawy J., Choisis N., Choisis J., Joannon A., Gibon A. 2012. Mixed crop-livestock systems: an economic and environmental-friendly way of farming? Animal 6(10), 1722-1730.

Trindade H. 2013. Portuguese dairy farming systems. Grassland Sci. Eur. 20, 21-25.

Wiatrak A. 2005. Zarządzanie przedsiębiorstwem rolniczym - istota i uwarunkowania. Pr. Wydz. Nauk Przyr. Byd. Tow. Nauk. 58, 611 
Streszczenie. Podstawową determinantą sytuacji ekonomicznej i sposobu zarządzania gospodarstwem jest system produkcji. Dotyczy to także gospodarstw zajmujących się produkcją żywca wołowego, położonych na terenie Unii Europejskiej. Gospodarstwa europejskie są zróżnicowane pod względem źródła pochodzenia zwierząt przeznaczanych na opas oraz sposobu prowadzenia chowu bydła rzeźnego. Celem podjętych badań jest wskazanie różnic w kosztach produkcji oraz dochodu gospodarstw charakteryzujących się różnymi systemami produkcji żywca wołowego. Otrzymane wyniki wskazują, że występuje zależność pomiędzy kosztami produkcji a stosowanym systemem produkcji żywca wołowego. Biorąc jednak pod uwagę dochód rolniczy netto, nie można jednoznacznie wskazać, że gospodarstwa prowadzące opas bydła ras mięsnych charakteryzują się wyższym dochodem niż gospodarstwa, dla których źródłem pozyskania zwierząt do opasu jest produkcja mleka. 
